\title{
Levosimendan use in critical care - a case series
}

\author{
C Gibson ${ }^{*}$, R Appelboam \\ From ESICM LIVES 2015 \\ Berlin, Germany. 3-7 October 2015
}

\section{Introduction}

Levosimendan is a calcium sensitiser that enhances myocardial contractility without increasing myocardial oxygen consumption or adversely affecting diastolic function. Whilst theoretically attractive, lack of outcome data in critically ill patients means that it is not yet established in intensive care practice. We have been using levosimendan on our Intensive Care Unit (ICU) for more than 6 years and the data presented here represents one of the largest case series on the use of levosimendan in this setting.

\section{Objectives}

To retrospectively analyse the cases of patients on a general ICU who were treated with levosimendan.

\section{Methods}

Our electronic patient record was used to identify patients who had been treated with levosimendan between 2009 and 2014. Patients' notes were analysed for demographic and clinical data. Subgroups for each answer were predefined and the best fit answer was decided by the investigator. A second search (2011-2013) was used to identify 2 matched control populations: acute myocardial infarction (AMI) and pneumonia. A chi-squared test was used to see if there was a difference in ICU outcomes between the matched controls and those treated with levosimendan.

\section{Results}

Over the 5 year period levosimendan was used in 90 patient cases. Exactly half the patients died in the ICU (Table 1).

$72 \%$ of patients had cardiac monitoring to aid diagnosis and response to treatment; $28 \%$ were treated on clinical grounds alone.

\footnotetext{
Royal Devon and Exeter Hospital, Intensive Care Medicine, Exeter, United
} Kingdom

Table 1

\begin{tabular}{lll}
\hline & $\begin{array}{l}\text { ICU survivors (Mean } \\
\text { (range)) }\end{array}$ & $\begin{array}{l}\text { ICU non-survivors (Mean } \\
\text { (range)) }\end{array}$ \\
\hline No. patients & 45 & 45 \\
\hline Age & $61(28-83)$ & $71(17-89)$ \\
\hline APACHE-2 score & $21(8-36)$ & $20(0-37)$ \\
\hline
\end{tabular}

Table 2 Indications for the use of levosimendan.

\begin{tabular}{lll}
\hline & No. cases \\
\hline Indication & $\begin{array}{l}\text { ICU } \\
\text { survivors }\end{array}$ & $\begin{array}{l}\text { ICU non- } \\
\text { survivors }\end{array}$ \\
\hline Ischaemic heart failure & 26 & 25 \\
\hline Sepsis induced cardiomyopathy & 10 & 14 \\
\hline $\begin{array}{l}\text { Acutely decompensated chronic heart } \\
\text { failure }\end{array}$ & 6 & 5 \\
\hline Right heart failure & 1 & 3 \\
\hline
\end{tabular}

$81 \%$ of patients were mechanically ventilated and $77 \%$ were already on vasoactive infusions.

3 patients were documented to have aortic stenosis, a contraindication to levosimendan.

$33 \%$ of patients had a $>20 \%$ fall in systolic blood pressure associated with the use of levosimendan. $6 \%$ had a new arrhythmia.

For patients with cardiac failure associated with AMI there was a statistically significant difference between the ICU mortality of those treated with or without levosimendan, favouring levosimendan. There were insufficient data to draw conclusions about those with pneumonia (Table 3).

\section{Conclusions}

In this case series, the most common indication for levosimendan use was heart failure secondary to AMI. We observed an ICU survival benefit in using levosimendan in this group of patients. This finding is supported by the RUSSLAN study that showed a shortterm survival benefit to using levosimendan in this 
Table 3

\begin{tabular}{llll}
\hline & Control & Levosimendan & p-value \\
\hline Pneumonia & & & \\
\hline APACHE-2 score & 23.7 & 23.9 & \\
\hline ICU mortality & $41 / 168=24 \%$ & $5 / 9=56 \%$ & N/A \\
\hline AMI & & & \\
\hline APACHE-2 score & 16.7 & 19.8 & \\
\hline ICU mortality & $47 / 78=60 \%$ & $25 / 51=49 \%$ & $\mathrm{p}=0.0247$ \\
\hline
\end{tabular}

patient group [1]. Whilst there is, to date, no evidence for a long-term mortality benefit in patients with AMI induced cardiac failure, there is supporting evidence for patients with acute decompensation of their chronic cardiac insufficiency [2].

Published: 1 October 2015

\section{References}

1. Moiseyev VS, Poder P, Andrejevs N, Ruda MY, Golikov AP, Lazebnik LB, et al: Safety and efficacy of a novel calcium sensitizer, levosimendan, in patients with left ventricular failure due to an acute myocardial infarction. A randomized, placebo-controlled, double-blind study (RUSSLAN). Eur Heart J 2002, 23(18):1422-1432.

2. Follath F, Cleland JG, Just H, Papp JG, Scholz H, Peuhkurinen $\mathrm{K}$, et al: Efficacy and safety of intravenous levosimendan compared with dobutamine in severe low-output heart failure: a randomised doubleblind trial. Lancet 2002, 360(9328):196-202. care - a case series. Intensive Care Medicine Experimental 2015 3(Suppl 1): A540.

\section{Submit your manuscript to a SpringerOpen ${ }^{\mathcal{O}}$ journal and benefit from:}

- Convenient online submission

- Rigorous peer review

- Immediate publication on acceptance

- Open access: articles freely available online

- High visibility within the field

- Retaining the copyright to your article 